\title{
The effects of buthionine sulfoximine, diethyldithiocarbamate or 3-amino-1,2,4-triazole on propyl gallate-treated HeLa cells in relation to cell growth, reactive oxygen species and glutathione
}

\author{
YONG HWAN HAN, HWA JIN MOON, BO RA YOU, SUNG ZOO KIM, SUHN HEE KIM and WOO HYUN PARK
}

Department of Physiology, Medical School, Centers for Healthcare Technology Development, Institute for Medical Sciences, Chonbuk National University, JeonJu 561-180, Korea

Received January 26, 2009; Accepted April 27, 2009

DOI: 10.3892/ijmm_00000229

\begin{abstract}
Propyl gallate (PG) as a synthetic antioxidant is widely used in processed food and medicinal preparations. It also exerts a variety of effects on tissue and cell functions. In the present study, we investigated the effects of L-buthionine sulfoximine (BSO, an inhibitor of GSH synthesis), diethyldithiocarbamate (DDC, an inhibitor of $\mathrm{Cu} / \mathrm{Zn}$-SOD) or 3amino-1,2,4-Triazole (AT, an inhibitor of catalase) on PGtreated HeLa cells in relation to cell growth, reactive oxygen species (ROS) and glutathione (GSH). Treatment with PG induced growth inhibition, the loss of mitochondrial membrane potential [MMP $\left.\left(\Delta \Psi_{\mathrm{m}}\right)\right]$ and apoptosis in HeLa cells. ROS levels including $\mathrm{O}_{2}{ }^{-}$- were increased or decreased in PG-treated HeLa cells depending on the incubation times. PG caused depletion in GSH content in HeLa cells. While BSO enhanced the growth inhibition of PG-treated HeLa cells at $4 \mathrm{~h}, \mathrm{DDC}$ and AT did not. All the agents down-regulated $\operatorname{MMP}\left(\Delta \Psi_{\mathrm{m}}\right)$ levels in PG-treated cells. Although BSO, DDC or AT slightly increased ROS or $\mathrm{O}_{2}{ }^{--}$levels in PG-treated cells at $1 \mathrm{~h}$, these enhancements of ROS did not intensify apoptosis in these cells. In addition, BSO, DDC or AT slightly reduced GSH level in PG-treated HeLa cells at $1 \mathrm{~h}$, but this reduction did not affect cell death of HeLa. Furthermore, PG
\end{abstract}

Correspondence to: Dr Woo Hyun Park, Department of Physiology, Medical School, Chonbuk National University, JeonJu 561-180, Korea

E-mail: parkwh71@chonbuk.ac.kr

Abbreviations: PG, propyl gallate; ROS, reactive oxygen species; $\operatorname{MMP}\left(\Delta \Psi_{\mathrm{m}}\right)$, mitochondrial membrane potential; NADPH, nicotine adenine diphosphate; XO, xanthine oxidase; SOD, superoxide dismutase; FBS, fetal bovine serum; PBS, phosphate buffer saline; FITC, fluorescein isothiocyanate; $\mathrm{H}_{2}$ DCFDA, 2', 7'-dichlorodihydrofluorescein diacetate; DHE, dihydroethidium; GSH, glutathione; CMFDA, 5-chloromethylfluorescein diacetate; MTT, 3-(4,5-dimethylthiazol-2-yl)-2,5-diphenyltetrazolium bromide; PI, propidium iodide; DDC, diethyldithiocarbamate; BSO, L-buthionine sulfoximine; AT, 3-amino-1,2,4-triazole

Key words: propyl gallate, apoptosis, HeLa, glutathione, reactive oxygen species induced a G1 phase arrest of the cell cycle. BSO, DDC or AT significantly inhibited the G1 phase arrest in PG-treated cells. Conclusively, the changes of ROS and GSH levels by BSO, DDC or AT in PG-treated HeLa cells did not strongly affect the cell growth and death.

\section{Introduction}

Propyl gallate [PG, 3,4,5-trihydroxybenzoic acid propyl ester (Fig. 1A)] is used as a synthetic antioxidant in processed food, cosmetics and food packing materials, to prevent rancidity and spoilage. PG is also used to preserve and stabilize medicinal preparations on the US Food and Drug Administration list (1). Because of its prevalent usage, the potential toxicity of $\mathrm{PG}$ has been investigated in vivo $(2,3)$ and in vitro, to assess various toxicological properties, i.e., mutagenicity (4) and cytogenetic effects (5). Despite the assumed low toxicity of PG, it exerts a variety of effects on tissue and cell functions. Several studies demonstrate the benefits of PG as an antioxidant $(3,6,7)$ and an anti-inflammatory agent (8). For instance, PG is an efficient protector of liver cells from lipid peroxidation by oxygen radicals (3). PG also has protective effects against oxidative DNA damage using 8-oxoguanine formation as a marker (7). In contrast, it is reported that PG has prooxidant properties $(9,10)$. PG is cytotoxic to isolated rat hepatocytes because it impairs mitochondria, leading to ATP depletion (11). PG inhibits growth of microorganisms by inhibiting respiration and nucleic acid synthesis (12). Controversially, the effects of PG on carcinogenesis and mutagenesis can be both enhancing and suppressing $(4,13)$. Antioxidative and cytoprotective properties of PG may change to prooxidative, cytotoxic and genotoxic properties in the presence of $\mathrm{Cu}(\mathrm{II})$ (14). Therefore, in order to clarify the discrepancy between the different effects of PG, further studies need to be performed to reevaluate its function and safety on cells and tissues.

Reactive oxygen species (ROS) include hydrogen peroxide $\left(\mathrm{H}_{2} \mathrm{O}_{2}\right)$, superoxide anion $\left(\mathrm{O}_{2}{ }^{\circ}\right)$ and hydroxyl radical $\left({ }^{\circ} \mathrm{OH}\right)$. These molecules have recently been implicated in regulating many important cellular events, including transcription factor activation, gene expression, differentiation and cell proliferation $(15,16)$. ROS are formed as by-products of mitochondrial respiration or the action of oxidases, including nicotine adenine diphosphate (NADPH) oxidase, xanthine oxidase (XO) and 
certain arachidonic acid oxygenases (17). A change in the redox state of a tissue implies a change in ROS generation or metabolism. The principal metabolic pathways include superoxide dismutase (SOD), which is expressed as extracellular, intracellular and mitochondrial isoforms. These isoforms metabolize $\mathrm{O}_{2}{ }^{--}$to $\mathrm{H}_{2} \mathrm{O}_{2}$. Further metabolism by peroxidases, which include catalase and glutathione (GSH) peroxidase, yields $\mathrm{O}_{2}$ and $\mathrm{H}_{2} \mathrm{O}$ (18). GSH is the main nonprotein antioxidant in the cell and provides electrons for enzymes such as glutathione peroxidase, which reduce $\mathrm{H}_{2} \mathrm{O}_{2}$ to $\mathrm{H}_{2} \mathrm{O}$. GSH has been shown to be crucial for cell proliferation, cell cycle progression and apoptosis $(19,20)$ and is known to protect cells from toxic insult by detoxifying toxic metabolites of drugs and ROS (21). Although cells possess antioxidant systems to control their redox state, which is important for their survival, excessive production of ROS can be induced and gives rise to the activation of events that lead to death or survival in different cell types (22-24).

Little is known about the relationship among PG, ROS and GSH in cancer cells. Because we recently observed that PG treatment inhibited the growth of HeLa cells via caspasedependent apoptosis (unpublished data), in the present study, we investigated the effects of L-buthionine sulfoximine [BSO, an inhibitor of GSH synthesis (25)], diethyldithiocarbamate [DDC, an inhibitor of $\mathrm{Cu} / \mathrm{Zn}-\mathrm{SOD}$ (26)] or 3amino-1,2,4-Triazole [AT, an inhibitor of catalase (27)] on PG-treated HeLa cells in relation to cell growth, ROS and GSH.

\section{Materials and methods}

Cell culture. The human cervix adenocarcinoma HeLa cells were obtained from the American Type Culture Collection (ATCC, Manassas, VA) and maintained in a humidified incubator containing $5 \% \mathrm{CO}_{2}$ at $37^{\circ} \mathrm{C}$. HeLa cells were cultured in RPMI-1640 supplemented with $10 \%$ fetal bovine serum (FBS) and 1\% penicillin-streptomycin (Gibco-BRL, Grand Island, NY). Cells were routinely grown in $100 \mathrm{~mm}$ plastic tissue culture dishes (Nunc, Roskilde, Denmark) and harvested with a solution of trypsin-EDTA while in a logarithmic phase of growth. Cells were maintained in these culture conditions for all experiments.

Reagents. PG was purchased from the Sigma-Aldrich Chemical Company (St. Louis, MO). PG was dissolved in ethanol at $200 \mathrm{mM}$ as a stock solution. L-buthionine sulfoximine (BSO), diethyldithiocarbamate (DDC) and 3amino-1,2,4-triazole (AT) were also obtained from Sigma. These agents were dissolved in water or ethanol at $100 \mathrm{mM}$ as a stock solution. Cells were pretreated with BSO, DDC or AT for 30 min prior to treatment with PG. Ethanol was used as a control vehicle. All stock solutions were wrapped in foil and kept at $4^{\circ} \mathrm{C}$ or $-20^{\circ} \mathrm{C}$.

Cell growth assay. The effect of drugs on HeLa cell growth was determined by trypan blue exclusion cell counting or measuring 3-(4,5-dimethylthiazol-2-yl)-2,5-diphenyltetrazolium bromide (MTT) dye absorbance of living cells as previously described (28). In brief, cells $\left(2 \times 10^{5}\right.$ cells per well) were seeded in 24-well plates (Nunc, Roskilde, Denmark) for
A
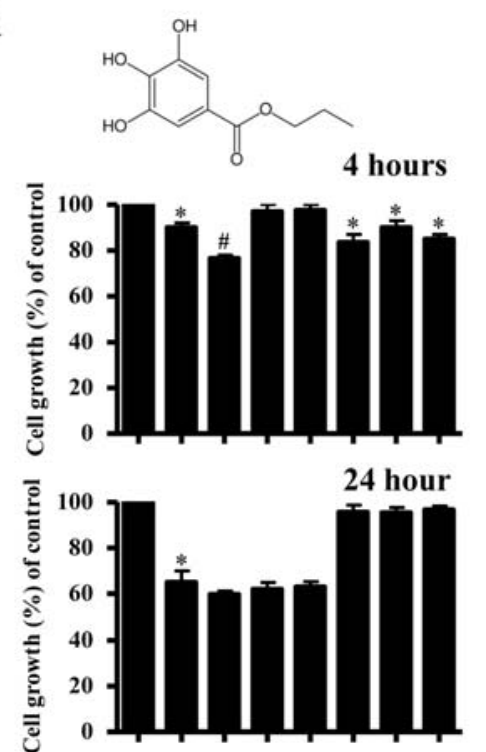

B

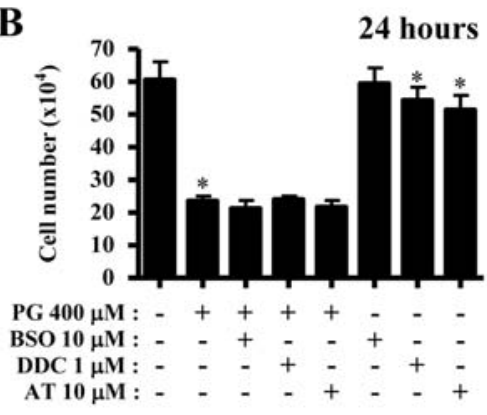

Figure 1. Effects of BSO, DDC or AT on the growth of PG-treated HeLa cells. The structure of propyl gallate (PG) is shown (A). Exponentiallygrowing cells were treated with $400 \mu \mathrm{M}$ PG for 4 or $24 \mathrm{~h}$ following $30 \mathrm{~min}$ pre-incubation of $10 \mu \mathrm{M}$ BSO, $1 \mu \mathrm{M}$ DDC or $10 \mu \mathrm{M}$ AT. Cell growth (A) and cell number (B) were assessed by an MTT assay and trypan blue exclusion cell counting, respectively. ${ }^{*} \mathrm{P}<0.05$ compared with the control group. ${ }^{\#} \mathrm{P}<0.05$ compared with cells treated with $\mathrm{PG}$ only. Data are presented as means $\pm \mathrm{SD}$ of three replicates.

cell counting, and cells $\left(2 \times 10^{4}\right.$ cells per well $)$ were seeded in 96-well microtiter plates for an MTT assay. After exposure to $400 \mu \mathrm{M}$ PG with or without BSO, DDC or AT for 4 or $24 \mathrm{~h}$, cells in 24- or 96-well plates were collected with trypsin digestion for trypan blue exclusion cell counting or were used for the MTT assay. Twenty microliters of MTT (Sigma) solution $(2 \mathrm{mg} / \mathrm{ml}$ in PBS) were added to each well of 96well plates. The plates were incubated for $4 \mathrm{~h}$ at $37^{\circ} \mathrm{C}$. MTT solution in the medium was aspirated off and $200 \mu 1 \mathrm{DMSO}$ were added to each well to solubilize the formazan crystals formed in viable cells. Optical density was measured at $570 \mathrm{~nm}$ using a microplate reader (Spectra MAX 340, Molecular Devices Co, Sunnyvale, CA). Each plate contained multiple wells at a given experimental condition and multiple control wells. This procedure was replicated for 2-4 plates per condition.

Cell cycle and sub-G1 analysis. Cell cycle distributions and sub-G1 cells were determined by propidium iodide (PI, Sigma-Aldrich; Ex/Em $=488 \mathrm{~nm} / 617 \mathrm{~nm}$ ) staining as previously described (29). PI is a fluorescent biomolecule that can be used to stain DNA. In brief, $1 \times 10^{6}$ cells were 
A

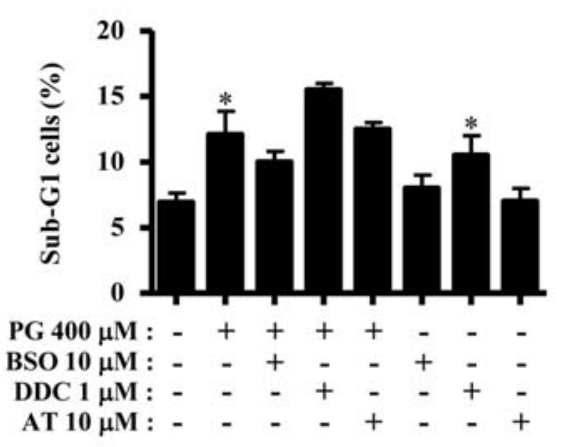

C

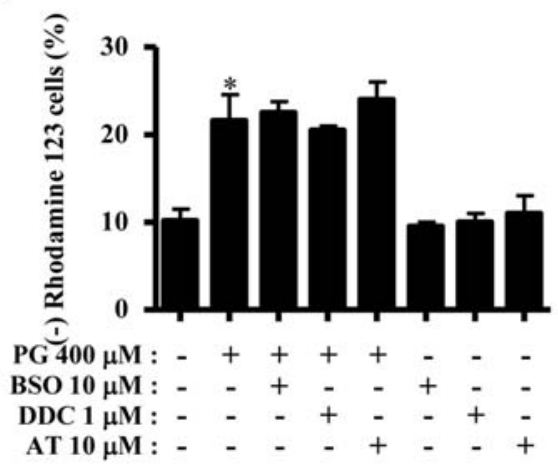

B

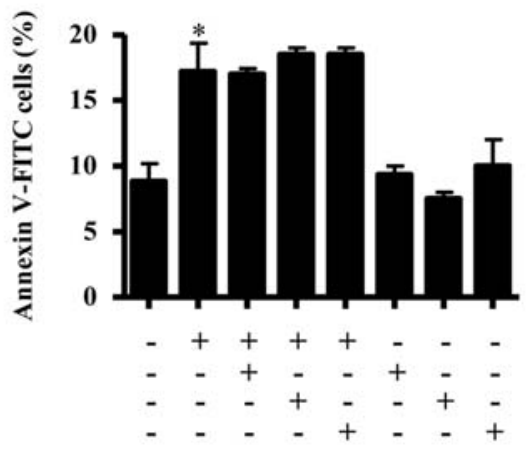

D

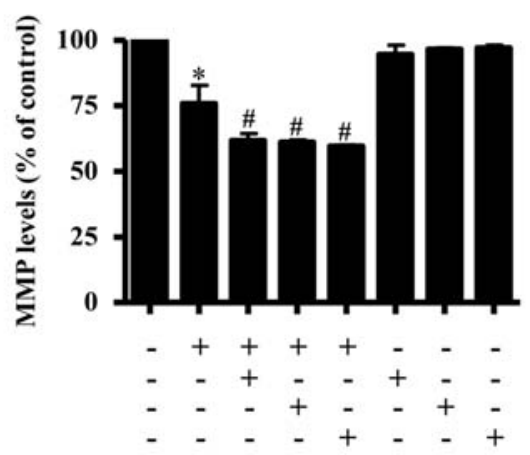

Figure 2. Effects of BSO, DDC or AT on apoptosis and MMP $\left(\Delta \Psi_{\mathrm{m}}\right)$ in PG-treated HeLa cells. Exponentially-growing cells were treated with $400 \mu \mathrm{M}$ PG for $24 \mathrm{~h}$ following $30 \mathrm{~min}$ pre-incubation of $10 \mu \mathrm{M}$ BSO, $1 \mu \mathrm{M}$ DDC or $10 \mu \mathrm{M}$ AT. Graphs show the percents of sub-G1 cells (A), annexin V staining cells (B), Rhodamine 123 negative [MMP $\left(\Delta \Psi_{\mathrm{m}}\right)$ loss] cells $(\mathrm{C})$ and MMP $\left(\Delta \Psi_{\mathrm{m}}\right)$ levels (D) in HeLa cells, as measured with a FACStar flow cytometer. ${ }^{*} \mathrm{P}<0.05$ compared with the control group. ${ }^{\#} \mathrm{P}<0.05$ compared with cells treated with PG only. Data are presented as means \pm SD of three replicates.

incubated with the indicated amounts of PG with or without BSO, DDC or AT for $24 \mathrm{~h}$. Cells were then washed with PBS and fixed in $70 \%$ ethanol. Cells were washed again with PBS, then incubated with PI $(10 \mu \mathrm{g} / \mathrm{ml})$ with simultaneous RNase treatment at $37^{\circ} \mathrm{C}$ for $30 \mathrm{~min}$. Cell DNA contents were measured using a FACStar flow cytometer (BectonDickinson, San Jose, CA) and analyzed using lysis II and CellFIT software (Becton-Dickinson) or ModFit software (Verity Software House, Inc., ME).

Annexin $V$ staining. Apoptosis was determined by staining cells with annexin V-fluorescein isothiocyanate (FITC) (Ex/ $\mathrm{Em}=488 \mathrm{~nm} / 519 \mathrm{~nm}$ ) as previously described (30). In brief, $1 \times 10^{6}$ cells were incubated with the indicated amounts of PG with or without BSO, DDC or AT for $24 \mathrm{~h}$. Cells were washed twice with cold PBS and then resuspended in $500 \mu 1$ of binding buffer (10 mM HEPES/NaOH pH 7.4, $140 \mathrm{mM}$ $\mathrm{NaCl}, 2.5 \mathrm{mM} \mathrm{CaCl}_{2}$ ) at a concentration of $1 \times 10^{6}$ cells $/ \mathrm{ml}$. Five microliters of annexin V-FITC (PharMingen, San Diego, CA) was then added to these cells, which were analyzed with a FACStar flow cytometer (Becton-Dickinson).

Measurement of mitochondrial membrane potential (MMP) $\left(\Delta \Psi_{m}\right)$. The MMP $\left(\Delta \Psi_{\mathrm{m}}\right)$ was monitored using the Rhodamine 123 fluorescent dye $(\mathrm{Ex} / \mathrm{Em}=485 / 535 \mathrm{~nm})$, which preferentially enters mitochondria based on their highly negative membrane potential $\left(\Delta \Psi_{\mathrm{m}}\right)$, as previously described
(31). Depolarization of MMP ( $\left.\Delta \Psi_{\mathrm{m}}\right)$ results in the loss of Rhodamine 123 and a decrease in intracellular fluorescence level. In brief, $1 \times 10^{6}$ cells were incubated with $400 \mu \mathrm{M}$ PG with or without BSO, DDC or AT for $24 \mathrm{~h}$. Cells were washed twice with PBS and incubated with Rhodamine 123 $(0.1 \mu \mathrm{g} / \mathrm{ml}$; Sigma $)$ at $37^{\circ} \mathrm{C}$ for $30 \mathrm{~min}$. Rhodamine 123 staining intensity was determined by flow cytometry. Rhodamine 123 negative cells indicate the loss of MMP $\left(\Delta \Psi_{\mathrm{m}}\right)$ in HeLa cells. MMP $\left(\Delta \Psi_{\mathrm{m}}\right)$ levels in cells except MMP $\left(\Delta \Psi_{\mathrm{m}}\right)$ loss cells were expressed as mean fluorescence intensity (MFI), which was calculated by CellQuest software.

Determination of intracellular $\mathrm{ROS}$ and $\mathrm{O}_{2}^{-*}$ levels. Intracellular ROS such as $\mathrm{H}_{2} \mathrm{O}_{2},{ }^{\circ} \mathrm{OH}$ and $\mathrm{ONOO}^{\bullet}$ were detected by means of an oxidation-sensitive fluorescent probe dye, 2',7'-dichlorodihydrofluorescein diacetate ( $\left.\mathrm{H}_{2} \mathrm{DCFDA}\right)$ (Invitrogen Molecular Probes, Eugene, OR) $(32,33) . \mathrm{H}_{2}$ DCFDA was deacetylated intracellularly by non-specific esterase, which was further oxidized by cellular peroxides, yielding 2,7-dichlorofluorescein (DCF), a fluorescent compound $(\mathrm{Ex} / \mathrm{Em}=495 / 529 \mathrm{~nm})$. DCF is poorly selective for superoxide anion radical $\left(\mathrm{O}_{2}{ }^{-}\right)$. In contrast, dihydroethidium $(\mathrm{DHE})(\mathrm{Ex} / \mathrm{Em}=518 / 605 \mathrm{~nm})$ (Invitrogen Molecular Probes) is a fluorogenic probe that is highly selective for $\mathrm{O}_{2}{ }^{-}$among ROS. DHE is cell-permeable and reacts with superoxide anion to form ethidium, which in turn intercalates in deoxyri- 
A

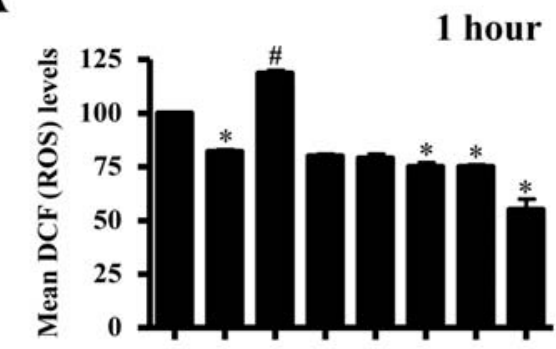

PG $400 \mu \mathrm{M}:-++++-\quad-$ BSO $10 \mu \mathrm{M}$ : - -+--+DDC $1 \mu \mathrm{M}:--\quad+--+-$ AT $10 \mu \mathrm{M}:--_{-}+-{ }_{-}+$

\section{B}

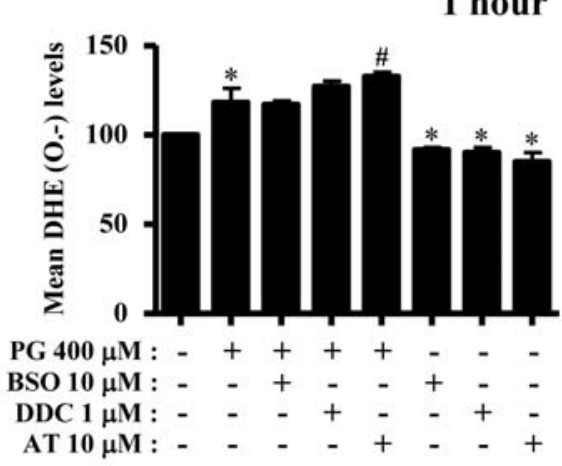

24 hours

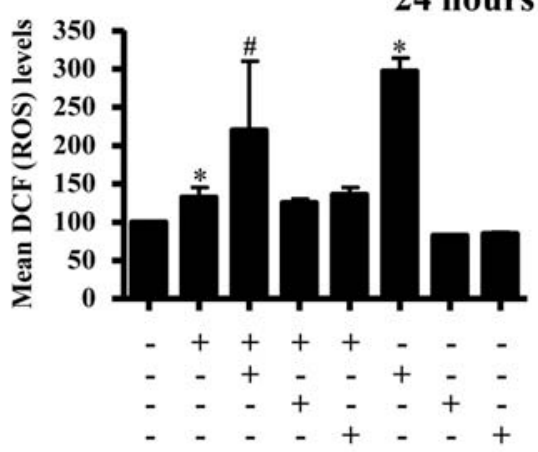

24 hours

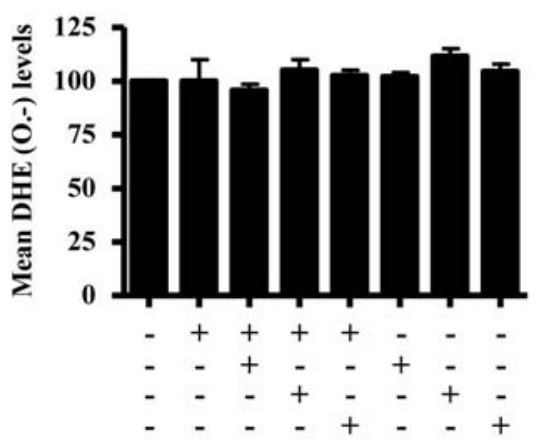

Figure 3. Effects of BSO, DDC or AT on ROS levels in PG-treated HeLa cells. Exponentially-growing cells were treated with $400 \mu \mathrm{M}$ PG for 1 or $24 \mathrm{~h}$ following 30 min pre-incubation of $10 \mu \mathrm{M}$ BSO, $1 \mu \mathrm{M}$ DDC or $10 \mu \mathrm{M}$ AT. ROS levels in HeLa cells were measured using a FACStar flow cytometer. Graphs indicate DCF (ROS) levels (\%) compared with HeLa control cells at 1 or $24 \mathrm{~h}(\mathrm{~A})$ and also indicate DHE $\left(\mathrm{O}_{2}{ }^{-}\right)$levels $(\%)$ compared with HeLa control cells at 1 and $24 \mathrm{~h}(\mathrm{~B}) .{ }^{*} \mathrm{P}<0.05$ compared with the control group. ${ }^{\#} \mathrm{P}<0.05$ compared with cells treated with $\mathrm{PG}$ only. Data are presented as means $\pm \mathrm{SD}$ of three replicates.

bonucleic acid, thereby exhibiting a red fluorescence. In brief, $1 \times 10^{6}$ cells were incubated with $400 \mu \mathrm{M}$ PG with or without BSO, DDC or AT for 1 or $24 \mathrm{~h}$. Cells were then washed in PBS and incubated with $20 \mu \mathrm{M} \mathrm{H}_{2}$ DCFDA or $\mathrm{DHE}$ at $37^{\circ} \mathrm{C}$ for $30 \mathrm{~min}$ according to the instructions of the manufacturer. DCF and DHE fluorescences were detected using a FACStar flow cytometer (Becton-Dickinson). ROS and $\mathrm{O}_{2}{ }^{-}$levels were expressed as mean fluorescence intensity (MFI), which was calculated by CellQuest software.

Detection of the intracellular glutathione (GSH). Cellular GSH levels were analyzed using 5-chloromethylfluorescein diacetate (CMFDA, Molecular Probes) $(\mathrm{Ex} / \mathrm{Em}=522 / 595 \mathrm{~nm})$ as previously described (33). In brief, $1 \times 10^{6}$ cells were incubated with the indicated amounts of PG with or without BSO, DDC or AT for 1 or $24 \mathrm{~h}$. Cells were then washed with PBS and incubated with $5 \mu \mathrm{M} \mathrm{CMFDA}$ at $37^{\circ} \mathrm{C}$ for $30 \mathrm{~min}$ according to the instructions of the manufacturer. Cytoplasmic esterases convert non-fluorescent CMFDA to fluorescent 5chloromethylfluorescein, which can then react with GSH. CMF fluorescence intensity was determined using a FACStar flow cytometer (Becton-Dickinson). Negative CMF staining (GSH depleted) cells were expressed as the percent of (-) CMF cells. CMF levels in cells except (-) CMF cells were expressed as mean fluorescence intensity (MFI), which was calculated by CellQuest software.
Statistical analysis. The results shown in Figures represent the mean of at least two independent experiments; bar, SD. The data were analyzed using Instat software (GraphPad Prism4, San Diego, CA). The student's t-test or one-way analysis of variance (ANOVA) with post hoc analysis using Tukey's multiple comparison test was used for parametric data. The statistical significance was defined as $\mathrm{p}<0.05$.

\section{Results}

Effects of BSO,DDC or AT on cell growth, apoptosis and mitochondrial membrane potential (MMP) $\left(\Delta \Psi_{m}\right)$ in $P G$ treated HeLa cells. We examined the effect of BSO, DDC or AT on the growth of PG-treated HeLa cells using the MTT assay and trypan blue cell counting at 4 or $24 \mathrm{~h}$ because PG treatment inhibited the growth of HeLa cells via caspasedependent apoptosis (Fig. 1 and unpublished data). For this experiment, we chose the suitable dose of $400 \mu \mathrm{M}$ PG, which inhibited the growth of HeLa cells about $40 \%$ using an MTT assay at $24 \mathrm{~h}$ (Fig. 1A) and about $60 \%$ using trypan blue cell counting at this time (Fig. 1B). We also determined the optimal doses of $10 \mu \mathrm{M}$ BSO, $1 \mu \mathrm{M}$ DDC and $10 \mu \mathrm{M}$ AT, concentrations of which did not strongly affect the growth of HeLa control cells at $24 \mathrm{~h}$ (Fig. 1). Treatment with BSO intensified the growth inhibition of PG-treated HeLa cells at the short time period of $4 \mathrm{~h}$ (Fig. 1A). BSO, DDC or AT 
alone inhibited the growth of HeLa control cells at this time (Fig. 1A). At 24 h, treatment with BSO, DDC or AT slightly increased the growth inhibition of PG-treated HeLa cells (Fig. 1A). None of BSO, DDC or AT significantly affected cell numbers in PG-treated HeLa cells, but DDC and AT reduced the number of HeLa control cells at $24 \mathrm{~h}$ (Fig. 1B).

We observed that $400 \mu \mathrm{M}$ PG induced apoptosis in HeLa cells about $8 \%$ compared with HeLa control cells, as evidenced by sub-G1 cells and annexin V staining cells (Fig. 2A and B). Apoptosis by PG was accompanied by the activation of caspases (unpublished data). We determined whether treatment with BSO, DDC or AT affect PG-induced apoptosis at 24 h. As shown in Fig. 2A, DDC slightly increased the number of sub-G1 cells in PG-treated and -untreated HeLa cells. Neither BSO nor AT affect that of sub-G1 cells in HeLa cells (Fig. 2A). In addition, none of these drugs affected the number of annexin V-FITC positive cells in PG-treated or PG-untreated cells (Fig. 2B).

Apoptosis is closely related to the collapse of MMP $\left(\Delta \Psi_{\mathrm{m}}\right)(34)$. Therefore, we determined the loss of MMP $\left(\Delta \Psi_{\mathrm{m}}\right)$ in PG-treated HeLa cells using a Rhodamine 123 dye. As expected, the loss of MMP $\left(\Delta \Psi_{\mathrm{m}}\right)$ was observed in PGtreated cells at $24 \mathrm{~h}$ (Fig. 2C). None of these drugs significantly changed the loss in PG-treated or -untreated cells (Fig. 2C). In relation to MMP $\left(\Delta \Psi_{\mathrm{m}}\right)$ levels in HeLa cells except Rhodamine 123 negative cells, treatment with PG reduced the MMP $\left(\Delta \Psi_{\mathrm{m}}\right)$ level about $25 \%$ (Fig. 2D). Treatment with BSO, DDC or AT additionally decreased the MMP $\left(\Delta \Psi_{\mathrm{m}}\right)$ level in PG-treated HeLa cells, but not in HeLa control cells (Fig. 2D).

Effects of BSO, DDC or AT on ROS levels in PG-treated HeLa cells. Next, to determine whether the levels of ROS in PG-treated HeLa cells were changed by treatment with BSO, DDC or AT, we assessed ROS levels in cells using various fluorescence dyes at the short time period of $1 \mathrm{~h}$ or the long time period of $24 \mathrm{~h}$ (Fig. 3). Intracellular ROS (DCF) level such as $\mathrm{H}_{2} \mathrm{O}_{2}$ was decreased in PG-treated cells at $1 \mathrm{~h}$ (Fig. 3A) whereas ROS level was increased in these cells at $24 \mathrm{~h}$ (Fig. 3A). Treatment with BSO increased ROS level in PGtreated HeLa cells at 1 or $24 \mathrm{~h}$, but DDC and AT did not affect the level of ROS in these cells (Fig. 3A). Interestingly, BSO, DDC and AT alone decreased ROS level in HeLa control cells at $1 \mathrm{~h}$ whereas BSO markedly increased ROS level at $24 \mathrm{~h}$ (Fig. 3A).

When we detected the intracellular $\mathrm{O}_{2}^{--}$levels in PGtreated HeLa cells, red fluorescence derived from DHE reflecting intracellular $\mathrm{O}_{2}{ }^{-}$level was increased in these cells at $1 \mathrm{~h}$ (Fig. 3B). Treatment with DDC or AT slightly intensified the increased $\mathrm{O}_{2}^{-}$level in PG-treated cells at $1 \mathrm{~h}$ (Fig. 3B). However, treatment with BSO, DDC or AT decreased $\mathrm{O}_{2}{ }^{-}$ level in HeLa control cells at $1 \mathrm{~h}$ (Fig. 3B). At $24 \mathrm{~h}, \mathrm{O}_{2}{ }^{-}$level in HeLa cells was not significantly changed by treatment with PG, BSO, DDC or AT (Fig. 3B).

Effects of BSO,DDC or AT on GSH levels in PG-treated HeLa cells. Cellular GSH is crucial for regulation of cell proliferation, cell cycle progression and apoptosis $(19,20)$. Therefore, we analyzed the changes of GSH levels in HeLa
A

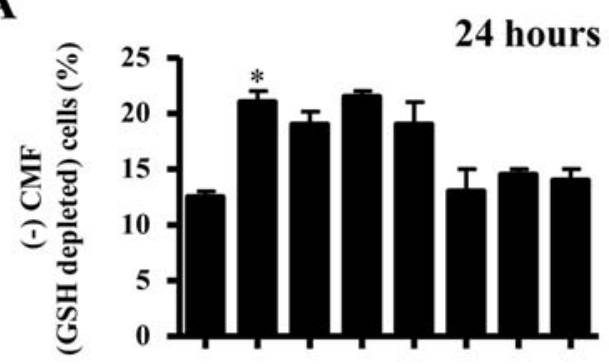

B
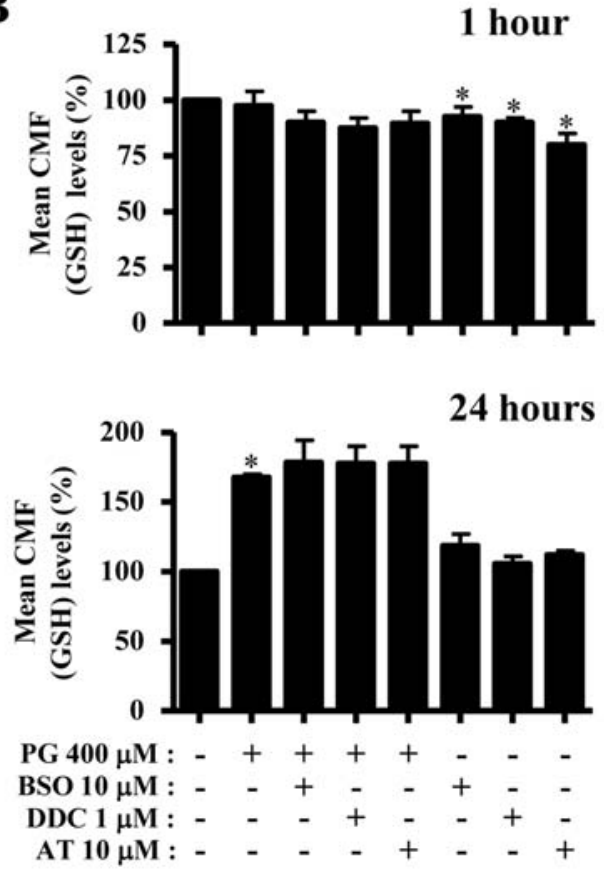

Figure 4. Effects of BSO, DDC or AT on GSH levels in PG-treated HeLa cells. Exponentially-growing cells were treated with $400 \mu \mathrm{M}$ PG for 1 or $24 \mathrm{~h}$ following $30 \mathrm{~min}$ pre-incubation of $10 \mu \mathrm{M}$ BSO, $1 \mu \mathrm{M}$ DDC or $10 \mu \mathrm{M}$ AT. GSH levels in HeLa cells were measured using a FACStar flow cytometer. Graphs indicate (-) CMF (GSH depleted) cells (\%) at $24 \mathrm{~h}$ of incubation time (A). Other graphs indicate mean CMF (GSH) levels (\%) compared with HeLa control at 1 or $24 \mathrm{~h}(\mathrm{~B}) .{ }^{*} \mathrm{P}<0.05$ compared with the control group. ${ }^{\#} \mathrm{P}<0.05$ compared with cells treated with $\mathrm{PG}$ only. Data are presented as means \pm SD of duplicates.

cells by using CMF fluorescence at 1 or $24 \mathrm{~h}$ (Fig. 4). Treatment with PG depleted the intracellular GSH content at $24 \mathrm{~h}$ in HeLa cells about $9 \%$ compared with the HeLa control cells (Fig. 4A), but not at $1 \mathrm{~h}$ (data not shown). Treatment with BSO, DDC or AT did not significantly affect GSH depletion in PG-treated HeLa cells (Fig. 4A). When CMF (GSH) levels in HeLa cells were assessed, PG did not change GSH level at $1 \mathrm{~h}$ (Fig. 4B). BSO, DDC or AT slightly reduced GSH level in PG-treated and -untreated HeLa cells at $1 \mathrm{~h}$ (Fig. 4B). At 24 h, PG treatment significantly increased GSH levels in HeLa cells, and none of drugs changed the GSH level in PG-treated or -untreated HeLa cells (Fig. 4B).

Effects of BSO,DDC or AT on the cell cycle distribution in PG-treated HeLa cells. We examined the effect of PG on the cell cycle distribution in HeLa cells, except sub-G1 DNA content cells, in the presence or absence of BSO, DDC or AT. As shown in Fig. 5, DNA flow cytometric analysis indicated 


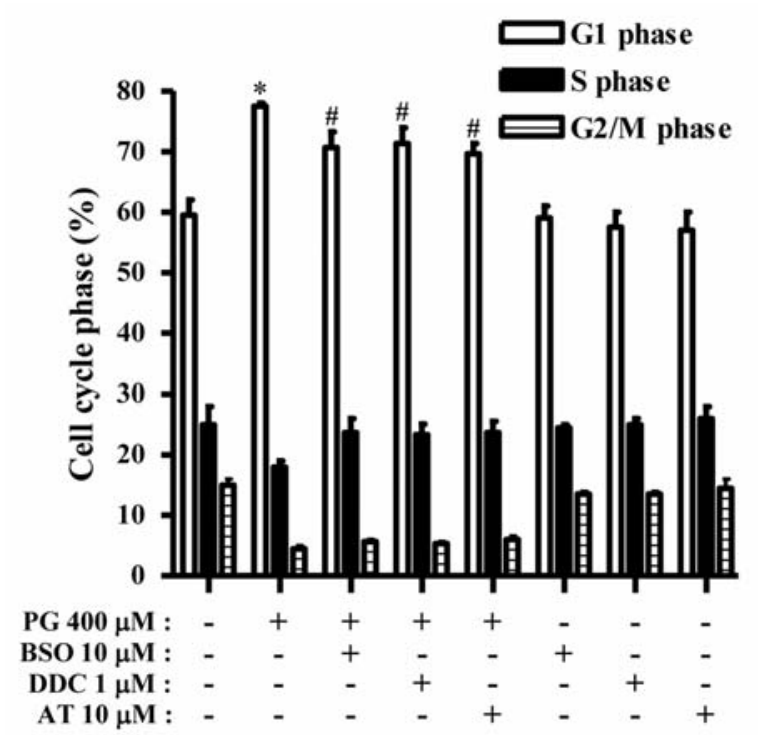

Figure 5. Effects of BSO, DDC or AT on the cell cycle distribution in PGtreated HeLa cells. Exponentially-growing cells were treated with $400 \mu \mathrm{M}$ PG for $24 \mathrm{~h}$ following 30 min pre-incubation of $10 \mu \mathrm{M}$ BSO, $1 \mu \mathrm{M}$ DDC or $10 \mu \mathrm{M}$ AT. The changes of cell cycle phase distribution were assessed by DNA flow cytometric analysis. ${ }^{*} \mathrm{P}<0.05$ compared with the control group. ${ }^{\#} \mathrm{P}<0.05$ compared with cells treated with $\mathrm{PG}$ only. Data are presented as means \pm SD of duplicates.

that treatment with PG significantly induced a G1 phase arrest of the cell cycle at $24 \mathrm{~h}$. Treatment with BSO, DDC or AT significantly reduced the number of cells at the G1 phase in PG-treated HeLa cells (Fig. 5).

\section{Discussion}

In the present study, we focused on evaluating the effects of BSO, DDC or AT on PG-treated HeLa cells in relation to cell growth, changes of ROS and GSH levels, since we have observed that PG inhibited the growth of HeLa cells. We also observed that PG induced apoptosis in HeLa cells, as evidenced by sub-G1 cells and annexin V staining cells. Treatment with BSO, DDC or AT slightly intensified the growth inhibition of PG-treated HeLa cells at $24 \mathrm{~h}$, as measured by the MTT assay. At $4 \mathrm{~h}$, especially BSO intensified the growth inhibition of PG-treated HeLa cells, and treatment with BSO, DDC or AT alone inhibited the growth of HeLa control cells. These results suggest that the effects of BSO, DDC or AT on HeLa cell growth depend on the incubation times. None of BSO, DDC or AT significantly affected cell numbers in PG-treated HeLa cells, but DDC and AT reduced the number of HeLa control cells at $24 \mathrm{~h}$. In addition, none of BSO, DDC or AT significantly increased the number of sub-G1 cells in PG-treated HeLa cells. None of these drugs affected the number of annexin V-FITC positive cells in PG-treated or -untreated cells. Collectively, these results suggest that co-treatment with PG and BSO, DDC or AT do not synergistically affect growth inhibition and apoptosis in HeLa cells. With regard to the MMP $\left(\Delta \Psi_{\mathrm{m}}\right)$, PG treatment induced the loss of MMP $\left(\Delta \Psi_{\mathrm{m}}\right)$ and reduced the MMP $\left(\Delta \Psi_{\mathrm{m}}\right)$ level in HeLa cells. None of BSO, DDC or AT significantly changed the level of MMP $\left(\Delta \Psi_{\mathrm{m}}\right)$ loss in
PG-treated or -untreated cells. These results imply that the loss of MMP $\left(\Delta \Psi_{\mathrm{m}}\right)$ following treatment with PG leads to apoptosis, and BSO, DDC and AT did not directly trigger the loss of MMP $\left(\Delta \Psi_{\mathrm{m}}\right)$. Furthermore, because MTT reduction is considered to be a measure of mitochondrial activity (35), the slightly decreased effect of BSO, DDC and AT on MTT reduction in PG-treated HeLa cells is probably due to the down-regulation of MMP $\left(\Delta \Psi_{\mathrm{m}}\right)$ levels by these agents. In addition, PG significantly induced a G1 phase arrest of the cell cycle at $24 \mathrm{~h}$. Treatment with BSO, DDC or AT significantly reduced the number of cells at the G1 phase in PG-treated HeLa cells. This result suggests that the preventive effect of BSO, DDC or AT on a G1 phase arrest in PGtreated HeLa cells is not directly related to HeLa cell growth.

PG can play a role as an antioxidant $(3,6,7,36)$ or a prooxidant $(9,10)$. Interestingly, our data showed that PG reduced ROS (DCF) levels for the short incubation time of $1 \mathrm{~h}$, but significantly increased the levels for the long incubation time of $24 \mathrm{~h}$. In contrast, PG increased $\mathrm{O}_{2}{ }^{--}$(DHE) levels for $1 \mathrm{~h}$, but this increase did not last for $24 \mathrm{~h}$. These data indicate that the intracellular ROS including $\mathrm{O}_{2}{ }^{*}$ were increased (prooxidant) or decreased (anti-oxidant) in PG-treated HeLa cells depending on the incubation times. A change in the redox state of cell or tissue implies a change in ROS generation or metabolism (18). SOD, which catalyzes the dismutation of $\mathrm{O}_{2}{ }^{-}$into $\mathrm{H}_{2} \mathrm{O}_{2}$ and molecular oxygen, is one of the most important antioxidative enzymes. Catalase then metabolizes $\mathrm{H}_{2} \mathrm{O}_{2}$ to $\mathrm{O}_{2}$ and $\mathrm{H}_{2} \mathrm{O}$. Treatment with $400 \mu \mathrm{M}$ PG increased the activities of SOD and catalase in HeLa cells at $24 \mathrm{~h}$ (unpublished data). Therefore, the increased ROS levels by PG did not result from the decreased activities of both SOD and catalase, but probably from the strong generation of ROS by other oxidases such as NADPH oxidase, XO and certain arachidonic acid oxygenases. Because Nakagawa et al suggests that PG mediates its toxicity by uncoupling the oxidative phosphorylation in mitochondrial respiration using isolated hepatocytes (37), it is also possible that PG can directly generate $\mathrm{O}_{2}{ }^{-}$in HeLa cells via impairing mitochondrial function. Since apoptosis in PG-treated cells was accompanied by an increase in ROS levels at $24 \mathrm{~h}$, this result suggests that the changes of ROS levels by PG are at least in part related to apoptotic cell death of HeLa.

When we determined whether the levels of intracellular ROS in PG-treated HeLa cells were changed by treatment with BSO, DDC or AT, treatment with BSO increased ROS level in PG-treated HeLa cells at 1 or $24 \mathrm{~h}$. Treatment with DDC or AT slightly intensified the increased $\mathrm{O}_{2}{ }^{-}$level in PG-treated cells at $1 \mathrm{~h}$. However, these enhancements of ROS did not intensify apoptosis in PG-treated cells. Therefore, the exact role of ROS in PG-induced cell death needs to be defined further. In general, the inhibition of SOD and catalase by DDC and AT in cells leads to an increase in ROS. However, our results demonstrated that treatment with DDC or AT did not increase ROS levels including $\mathrm{O}_{2}{ }^{-}$in HeLa control cells. Instead, both of them reduced ROS levels in HeLa control cells at $1 \mathrm{~h}$. When exposed to DDC for the long time of $72 \mathrm{~h}$, HeLa cells showed the increased level of $\mathrm{O}_{2}$. (data not shown). In addition, we observed an increased level of ROS in AT-treated Calu-6 lung cancer cells (unpublished 
data). These results suggest that the effects of DDC and AT on SOD and catalase activities depend on cell types and incubation times.

GSH directly eliminates $\mathrm{O}_{2}^{--}$and provides electrons for enzymes such as GSH peroxidase, which reduce $\mathrm{H}_{2} \mathrm{O}_{2}$ to $\mathrm{H}_{2} \mathrm{O}$. It has been reported that the intracellular $\mathrm{GSH}$ content has a decisive effect on anticancer drug-induced apoptosis, indicating that apoptotic effects are inversely comparative to GSH content $(38,39)$. Likewise, when PG depleted intracellular GSH content in HeLa cells for $24 \mathrm{~h}$, these cells showed apoptotic phenomenon. It is of note that CMF (GSH) level in HeLa cells was increased for $24 \mathrm{~h}$. Probably, an increase in GSH content happened to reduce the increasing ROS by PG. Thus, cells beyond their capacity to resist ROS would be immediately dead. Treatment with BSO, DDC or AT did not significantly affect GSH depletion in PG-treated HeLa cells. This result is probably correlated to the fact that BSO, DDC and AT did not affect growth inhibition and apoptosis in PG-treated HeLa cells. It is of note that BSO as a GSH synthesis inhibitor did not enhance the GSH depletion in PG-treated HeLa cells. However, we observed that BSO enhanced the GSH depletion and apoptosis in antimycin Atreated Calu-6 lung cells (unpublished data). It is possible that the effect of BSO on GSH depletion is dependent on cell types. Concerning GSH levels following treatment with BSO, DDC or AT, all of them slightly reduced GSH level in PG-treated and -untreated HeLa cells at $1 \mathrm{~h}$, but not $24 \mathrm{~h}$. These results suggest that the agents differently influence GSH levels in HeLa cells depending on the incubation times. Particularly, BSO has an effect on GSH level as well as ROS level in PG-treated HeLa cells at the early time of $1 \mathrm{~h}$. The precise role of the time-dependent changes of ROS level by these drugs needs to be defined further.

Conclusively, our data demonstrated that the changes of ROS and GSH levels by BSO, DDC or AT in PG-treated HeLa cells did not strongly affect the cell growth and death.

\section{Acknowledgements}

This study was supported by a grant of the Korea Healthcare Technology R\&D Project, Ministry for Health, Welfare \& Family Affairs, Korea (A084194) and the Korea Research Foundation Grant funded by the Government of Korea (MOEHRD).

\section{References}

1. Daniel JW: Metabolic aspects of antioxidants and preservatives. Xenobiotica 16: 1073-1078, 1986.

2. Dacre JC: Long-term toxicity study of n-propyl gallate in mice. Food Cosmet Toxicol 12: 125-129, 1974.

3. Wu TW, Fung KP, Zeng LH, Wu J and Nakamura H: Propyl gallate as a hepatoprotector in vitro and in vivo. Biochem Pharmacol 48: 419-422, 1994.

4. Rosin MP and Stich HF: Enhancing and inhibiting effects of propyl gallate on carcinogen-induced mutagenesis. J Environ Pathol Toxicol 4: 159-167, 1980.

5. Abdo KM, Huff JE, Haseman JK and Alden CJ: No evidence of carcinogenicity of D-mannitol and propyl gallate in F344 rats or B6C3F1 mice. Food Chem Toxicol 24: 1091-1097, 1986.

6. Reddan JR, Giblin FJ, Sevilla M, Padgaonkar V, Dziedzic DC, Leverenz VR, Misra IC, Chang JS and Pena JT: Propyl gallate is a superoxide dismutase mimic and protects cultured lens epithelial cells from $\mathrm{H}_{2} \mathrm{O}_{2}$ insult. Exp Eye Res 76: 49-59, 2003.
7. Chen $\mathrm{CH}$, Liu $\mathrm{TZ}$, Chen $\mathrm{CH}$, Wong $\mathrm{CH}$, Chen $\mathrm{CH}$, Lu FJ and Chen SC: The efficacy of protective effects of tannic acid, gallic acid, ellagic acid, and propyl gallate against hydrogen peroxideinduced oxidative stress and DNA damages in IMR-90 cells. Mol Nutr Food Res 51: 962-968, 2007.

8. Jeon WK and Kim BC: Heme oxygenase-1 mediates the antiinflammatory effect of propyl gallate in LPS-stimulated macrophages. Biochem Biophys Res Commun (In press).

9. Kobayashi H, Oikawa S, Hirakawa K and Kawanishi S: Metalmediated oxidative damage to cellular and isolated DNA by gallic acid, a metabolite of antioxidant propyl gallate. Mutat Res 558: 111-120, 2004.

10. Kawanishi S, Oikawa S and Murata M: Evaluation for safety of antioxidant chemopreventive agents. Antioxid Redox Signal 7: 1728-1739, 2005.

11. Nakagawa Y, Nakajima K, Tayama S and Moldeus P: Metabolism and cytotoxicity of propyl gallate in isolated rat hepatocytes: effects of a thiol reductant and an esterase inhibitor. Mol Pharmacol 47: 1021-1027, 1995.

12. Boyd I and Beveridge EG: Relationship between the antibacterial activity towards Escherichia coli NCTC 5933 and the physico-chemical properties of some esters of 3,4,5-trihydroxybenzoic acid (Gallic acid). Microbios 24: 173-184, 1979.

13. Miller C, Castonguay A and Teel RW: Modulation of the mutagenicity and metabolism of the tobacco-specific nitrosamine 4-(methylnitrosamino)-1-(3-pyridyl)-1-butanone (NNK) by phenolic compounds. Mutat Res 368: 221-233, 1996.

14. Jacobi H, Eicke B and Witte I: DNA strand break induction and enhanced cytotoxicity of propyl gallate in the presence of copper(II). Free Radic Biol Med 24: 972-978, 1998.

15. Gonzalez C, Sanz-Alfayate G, Agapito MT, Gomez-Nino A, Rocher A and Obeso A: Significance of ROS in oxygen sensing in cell systems with sensitivity to physiological hypoxia. Respir Physiol Neurobiol 132: 17-41, 2002.

16. Baran CP, Zeigler MM, Tridandapani S and Marsh CB: The role of ROS and RNS in regulating life and death of blood monocytes. Curr Pharm Des 10: 855-866, 2004.

17. Zorov DB, Juhaszova M and Sollott SJ: Mitochondrial ROSinduced ROS release: An update and review. Biochim Biophys Acta 1757: 509-517, 2006.

18. Wilcox CS: Reactive oxygen species: roles in blood pressure and kidney function. Curr Hypertens Rep 4: 160-166, 2002.

19. Poot M, Teubert H, Rabinovitch PS and Kavanagh TJ: De novo synthesis of glutathione is required for both entry into and progression through the cell cycle. J Cell Physiol 163: 555-560, 1995.

20. Schnelldorfer T, Gansauge S, Gansauge F, Schlosser S, Beger HG and Nussler AK: Glutathione depletion causes cell growth inhibition and enhanced apoptosis in pancreatic cancer cells. Cancer 89: 1440-1447, 2000.

21. Lauterburg BH: Analgesics and glutathione. Am J Ther 9: 225-233, 2002.

22. Dasmahapatra G, Rahmani M, Dent P and Grant S: The tyrphostin adaphostin interacts synergistically with proteasome inhibitors to induce apoptosis in human leukemia cells through a reactive oxygen species (ROS)-dependent mechanism. Blood 107: 232-240, 2006.

23. Wallach-Dayan SB, Izbicki G, Cohen PY, Gerstl-Golan R, Fine A and Breuer R: Bleomycin initiates apoptosis of lung epithelial cells by ROS but not by Fas/FasL pathway. Am J Physiol Lung Cell Mol Physiol 290: L790-L796, 2006.

24. Shim HY, Park JH, Paik HD, Nah SY, Kim DS and Han YS: Acacetin-induced apoptosis of human breast cancer MCF-7 cells involves caspase cascade, mitochondria-mediated death signaling and SAPK/JNK1/2-c-Jun activation. Mol Cells 24: 95-104, 2007.

25. Bailey HH: L-S,R-buthionine sulfoximine: historical development and clinical issues. Chem Biol Interact 111-112: 239-254, 1998.

26. Cocco D, Calabrese L, Rigo A, Argese E and Rotilio G: Reexamination of the reaction of diethyldithiocarbamate with the copper of superoxide dismutase. J Biol Chem 256: 8983-8986, 1981.

27. Margoliash E and Novogrodsky A: A study of the inhibition of catalase by 3-amino-1:2:4:-triazole. Biochem J 68: 468-475, 1958.

28. Park WH, Seol JG, Kim ES, Hyun JM, Jung CW, Lee CC, Kim BK and Lee YY: Arsenic trioxide-mediated growth inhibition in MC/CAR myeloma cells via cell cycle arrest in association with induction of cyclin-dependent kinase inhibitor, p21, and apoptosis. Cancer Res 60: 3065-3071, 2000. 
29. Han YH, Kim SZ, Kim SH and Park WH: Arsenic trioxide inhibits the growth of Calu- 6 cells via inducing a G2 arrest of the cell cycle and apoptosis accompanied with the depletion of GSH. Cancer Lett (In press).

30. Han YH, Kim SZ, Kim SH and Park WH: Apoptosis in pyrogallol-treated Calu- 6 cells is correlated with the changes of intracellular GSH levels rather than ROS levels. Lung Cancer 59: 301-314, 2008.

31. Han YH, Kim SZ, Kim SH and Park WH: Arsenic trioxide inhibits growth of As4.1 juxtaglomerular cells via cell cycle arrest and caspase-independent apoptosis. Am J Physiol Renal Physiol 293: F511-F520, 2007.

32. Setsukinai K, Urano Y, Kakinuma K, Majima HJ and Nagano T: Development of novel fluorescence probes that can reliably detect reactive oxygen species and distinguish specific species. J Biol Chem 278: 3170-3175, 2003.

33. Han YH, Kim SH, Kim SZ and Park WH: Caspase inhibitor decreases apoptosis in pyrogallol-treated lung cancer Calu-6 cells via the prevention of GSH depletion. Int J Oncol 33: 1099-1105, 2008.

34. Yang J, Liu X, Bhalla K, Kim CN, Ibrado AM, Cai J, Peng TI, Jones DP and Wang X: Prevention of apoptosis by Bcl-2: release of cytochrome c from mitochondria blocked. Science 275: 1129-1132, 1997.
35. Berridge MV and Tan AS: Characterization of the cellular reduction of 3-(4,5-dimethylthiazol-2-yl)-2,5-diphenyltetrazolium bromide (MTT): subcellular localization, substrate dependence, and involvement of mitochondrial electron transport in MTT reduction. Arch Biochem Biophys 303: 474-482, 1993.

36. Raghavan S and Hultin HO: Model system for testing the efficacy of antioxidants in muscle foods. J Agric Food Chem 53: 4572-4577, 2005.

37. Nakagawa Y and Tayama S: Cytotoxicity of propyl gallate and related compounds in rat hepatocytes. Arch Toxicol 69: 204-208, 1995.

38. Higuchi Y: Glutathione depletion-induced chromosomal DNA fragmentation associated with apoptosis and necrosis. J Cell Mol Med 8: 455-464, 2004.

39. Park WH, Han YW, Kim SH and Kim SZ: A superoxide anion generator, pyrogallol induces apoptosis in As4.1 cells through the depletion of intracellular GSH content. Mutat Res 619: $81-92,2007$ 